\title{
YIELD COMPONENT ANALYSIS AND DIVERSITY IN JERUSALEM ARTICHOKE (Helianthus tuberosus L.)
}

\author{
Sikora, V. ${ }^{*}$, Berenji, J. $^{1}$ and Latković, D. ${ }^{2}$ \\ ${ }^{1}$ Institute of Field and Vegetable Crops, Maksima Gorkog 30, \\ 21000 Novi Sad, Serbia \\ ${ }^{2}$ University of Novi Sad, Faculty of Agriculture, Square Dositeja Obradovića 8, \\ 21000, Novi Sad, Serbia
}

Received: April 12, 2010

Accepted: August 10, 2010

\begin{abstract}
SUMMARY
The objective of this study was to analyze the variability and mutual dependence of the tuber weight per plant, tuber number per plant, average tuber weight and total sugars content in the tubers of 20 Jerusalem artichoke genotypes included in a varietal trial conducted in the period 1994-2008. The variability of tuber weight per plant, tuber number per plant and average tuber weight was significantly affected by environmental conditions, while the total sugars content in the tubers depended primarily on the genotype. As the tuber weight per plant increased, the content of total sugars in the tubers decreased. Maximum tuber weight per plant was achieved with the genotype BT-4 and highest contents of total sugars in tubers were found in the genotypes Violet Rennes, UKR 5/82 and Topianca.
\end{abstract}

Key words: diversity, Helianthus tuberosus L., Jerusalem artichoke, variability, yield components

\section{INTRODUCTION}

Together with the sunflower, the Jerusalem artichoke (Helianthus tuberosus L.) is the only cultivated crop from the genus Helianthus. Jerusalem artichoke is a perennial plant native to North America, widespread in all parts of the world including Serbia. It is a frequent weed plant of pastures and fallow land (Wyse et al., 1986). Aboveground plant parts and tubers are used as cattle feed. Tubers, also known as food of the poor, have a high content of carbohydrates which makes them interesting for the production of sweeteners, low-calory food additives and bioethanol (Kišgeci et al., 1988; Meijer et al., 1993; Mullin et al., 1994). In sunflower breeding programs, the Jerusalem artichoke serves for broadening the genetic

* Corresponding author: Phone: +381 21780 365; Fax: +381 21780 399;

e-mail: sikora@ifvens.ns.ac.rs 
basis of sunflowers, primarily the resistance to plant pathogens (Korell et al., 1996a, b; Suseelana et al., 2002).

The objective of this study was, based on data from multi-year experiments, to analyze the variability and mutual dependence of yield components, and to assess the diversity of the Jerusalem artichoke genotypes in the collection maintained at Institute of Field and Vegetable Crops in Novi Sad (Serbia).

\section{MATERIALS AND METHODS}

The experiment was conducted at Bački Petrovac experiment field of Institute of Field and Vegetable Crops in Novi Sad in the period 1994-2008. A collection was tested that included 20 Jerusalem artichoke genotypes of different origin (Table 1).

Table 1: Collection of Jerusalem artichoke genotypes tested

\begin{tabular}{|c|c|c|}
\hline Number & Designation & Origin \\
\hline 1 & UKR $1 / 82$ & \multirow{5}{*}{$\begin{array}{l}\text { Genotypes obtained at Institute of Field and Vegetable Crops, Novi Sad, } \\
\text { Serbia, by spontaneous crossing and by maintaining the derived half- } \\
\text { sib progenies by vegetative propagation }\end{array}$} \\
\hline 2 & UKR 2/82 & \\
\hline 3 & UKR 4/82 & \\
\hline 4 & UKR 5/82 & \\
\hline 5 & UKR 6/82 & \\
\hline 6 & Banja Koviljača & A local population from Banja Koviljača, Serbia \\
\hline 7 & Violet Communes & \multirow{9}{*}{ I.N.R.A. Station d'Amélioration des Plantes, Le Rheu, France } \\
\hline 8 & Violet Rennes & \\
\hline 9 & Topianca & \\
\hline 10 & Fuseau 60 & \\
\hline 11 & Ozor & \\
\hline 12 & D-19 & \\
\hline 13 & $\mathrm{~K}-8$ & \\
\hline 14 & $207-63$ & \\
\hline 15 & $952-63$ & \\
\hline 16 & Waldspindel D & Institut für Pflanzenbau und Pflanzenzüchtung, Braunschweig, Germany \\
\hline 17 & Waldspindel A & Zuckerforshung-Institut, Fuchsenbigl, Austria \\
\hline 18 & Bela & Univerza Ljubljana, Biotehniška fakulteta, Ljubljana, Slovenia \\
\hline 19 & BT-3 & \multirow{2}{*}{ Agrobotanikai Központ, Tápiószele, Hungary } \\
\hline 20 & BT-4 & \\
\hline
\end{tabular}

Experiments were established each year on a chernozem soil, always changing the location and using tubers from the previous year. Planting was done in early spring, as soon as weather conditions would permit it (February-March). Tubers were planted manually, at a depth of $10 \mathrm{~cm}$. Elementary plots consisted of single rows spaced $1 \mathrm{~m}$ apart. Each row consisted of 20 plants planted $50 \mathrm{~cm}$ apart. This planting arrangement made a stand density of 20,000 plants $\mathrm{ha}^{-1}$.

During growing season, conventional cultivation practices were applied in the experiments (Berenji, 1994). At the end of growing season, after first frosts in the fall, all aboveground plant parts were removed from the experimental plots. 
Next spring, before planting, tubers of five randomly selected plants per genotype were dug out. Tubers originating from a single plant were considered as one replication. The following parameters were measured:

1. tuber number per plant;

2. tuber weight per plant, expressed in $\mathrm{kg}_{\text {plant }}{ }^{-1}$;

3. average tuber weight calculated for each plant by dividing the weight of tubers per plant with tuber number per plant;

4. 10 tubers per genotype were used to determine sugar content (\%) by measuring the dry-substance content with Abbe-refractometer.

Statistical analyses included ANOVA, average values, ranks, coefficient of variation $(\mathrm{CV})$, genetic $\left(\sigma_{\mathrm{g}}^{2}\right)$, ecological $\left(\sigma_{\mathrm{e}}^{2}\right)$ and phenotypic $\left(\sigma_{\mathrm{p}}^{2}\right)$ variances, broad-sense heritability $\left(\mathrm{h}^{2}\right)$, genetic and phenotypic correlation coefficients. A dendrogram was prepared to show phenotypic differences (Hill et al., 1998) in the collection of Jerusalem artichoke genotypes.

\section{RESULTS AND DISCUSSION}

Data on the mean values and rank of individual Jerusalem artichoke genotypes for the analyzed traits are given in Table 2 .

Table 2: Average values and ranks for the collection of Jerusalem artichoke genotypes traits tested in the period 1994-2008.

\begin{tabular}{clcccccccc}
\hline \multirow{2}{*}{\begin{tabular}{c}
\multirow{2}{*}{ Number Designation } \\
\cline { 3 - 9 }
\end{tabular}} & \multicolumn{2}{c}{$\begin{array}{c}\text { Tuber yield } \\
\text { per plant }(\mathrm{kg})\end{array}$} & $\begin{array}{c}\text { Number of tubers } \\
\text { per plant }\end{array}$ & $\begin{array}{c}\text { Tuber size } \\
(\mathrm{g})\end{array}$ & \multicolumn{2}{c}{$\begin{array}{c}\text { Sugar content } \\
(\%)\end{array}$} \\
\cline { 2 - 9 } & Average & Rank & Average & Rank & Average & Rank & Average & Rank \\
\hline 1 & UKR 1/82 & 2.08 & 8 & 45 & 3 & 49 & 13 & 24.0 & 11 \\
2 & UKR 2/82 & 1.54 & 18 & 34 & 9 & 44 & 14 & 26.2 & 6 \\
3 & UKR 4/82 & 2.16 & 6 & 37 & 7 & 61 & 6 & 25.2 & 9 \\
4 & UKR 5/82 & 1.40 & 19 & 33 & 10 & 43 & 15 & 27.1 & 2 \\
5 & UKR 6/82 & 2.37 & 4 & 44 & 4 & 53 & 9 & 25.7 & 8 \\
6 & Banja Koviljača & 1.69 & 17 & 22 & 15 & 80 & 1 & 24.0 & 11 \\
7 & Violet Communes & 1.88 & 11 & 31 & 11 & 66 & 4 & 24.3 & 10 \\
8 & Violet Rennes & 2.04 & 9 & 29 & 13 & 70 & 3 & 27.2 & 1 \\
9 & Topianca & 1.70 & 16 & 34 & 9 & 49 & 13 & 27.0 & 3 \\
10 & Fuseau 60 & 1.82 & 14 & 36 & 8 & 50 & 12 & 25.9 & 7 \\
11 & Ozor & 2.36 & 5 & 38 & 6 & 61 & 6 & 22.6 & 14 \\
12 & D-19 & 2.13 & 7 & 38 & 6 & 59 & 7 & 23.0 & 12 \\
13 & K-8 & 2.46 & 3 & 36 & 8 & 63 & 5 & 22.7 & 13 \\
14 & 207-63 & 1.28 & 20 & 27 & 14 & 50 & 12 & 22.2 & 16 \\
15 & 952-63 & 1.87 & 12 & 38 & 6 & 51 & 10 & 24.0 & 11 \\
16 & Waldspindel D & 2.03 & 10 & 39 & 5 & 52 & 11 & 26.7 & 4 \\
17 & Waldspindel A & 1.85 & 13 & 34 & 9 & 53 & 9 & 26.6 & 5 \\
18 & Bela & 1.77 & 15 & 30 & 12 & 57 & 8 & 22.3 & 15 \\
19 & BT-3 & 2.69 & 2 & 55 & 1 & 50 & 12 & 25.2 & 9 \\
20 & BT-4 & 3.27 & 1 & 46 & 2 & 78 & 2 & 22.7 & 13 \\
\hline Average & 2.02 & - & 36 & - & 57 & - & 24.7 & - \\
\hline LSD at P<0.05 & 0.48 & - & 7 & - & 11 & - & 1.0 & - \\
LSD at P<0.01 & 0.63 & - & 9 & - & 14 & - & 1.3 & - \\
\hline
\end{tabular}


Tuber weight per plant ranged from 1.28 to $3.27 \mathrm{~kg}$ plant $^{-1}$ or $2.02 \mathrm{~kg} \mathrm{plant}^{-1}$ on average, which gave calculated yields from 25.6 to $65.4 \mathrm{t} \mathrm{ha}^{-1}$ or $40.4 \mathrm{t} \mathrm{ha}^{-1}$ on average. BT-4, BT-3, K-8, UKR 6/82 and Ozor were the most productive genotypes whose calculated yields exceeded $50 \mathrm{t} \mathrm{ha}^{-1}$. According to the literature, the yield of the Jerusalem artichoke is highly variable, depending largely on environmental conditions and ranging from 28 to $128 \mathrm{t} \mathrm{ha}^{-1}$ (Kosarić et al., 1984). The yields obtained in this experiment were at the level of the yield of wild American genotypes (Seiler, 1993).

The average number of tubers per plant was 36, the lowest number (22) having been found in the genotype Banja Koviljača and largest (55) in the genotype BT-3. The genotypes Banja Koviljača, BT-4, Violet Rennes, Violet Communes and K-8 stood out for the average tuber weight which exceeded $60 \mathrm{~g}$. The results concerning tuber number and weight are identical with the results obtained in an earlier analysis (Berenji and Sikora, 2001).

The content of total sugars ranged in the collection from 18.0 to $27.2 \%$, with the average value of $24.7 \%$. High contents, over $27 \%$, were found in the genotypes Violet Rennes and UKR 5/82, while five genotypes (207-63, White, Ozor, BT-4 and K-8) had a multi-year average below $23 \%$. These values are significantly higher than those published in earlier papers (Klausthofer et al., 1987; Meijer et al., 1993; Schittenhelm, 1999).

Table 3: Variation coefficient $(\mathrm{CV})$, genetic $\left(\sigma_{\mathrm{g}}^{2}\right)$, ecological $\left(\sigma_{\mathrm{e}}^{2}\right)$ and phenotypic $\left(\sigma_{\mathrm{p}}^{2}\right)$ variances and broad-sense heritability $\left(\mathrm{h}^{2}\right)$ in the collection of Jerusalem artichoke genotypes.

\begin{tabular}{lccccc}
\hline Trait & $\mathrm{CV}(\%)$ & $\sigma_{\mathrm{g}}^{2}$ & $\sigma_{\mathrm{e}}^{2}$ & $\sigma_{\mathrm{p}}^{2}$ & $\mathrm{~h}^{2}(\%)$ \\
\hline Tuber yield per plant $(\mathrm{kg})$ & 47.12 & 0.181 & 0.457 & 0.638 & 28.4 \\
Tuber number per plant & 37.30 & 48.681 & 90.472 & 139.153 & 35.0 \\
Tuber size (g) & 36.05 & 89.84 & 233.725 & 323.566 & 27.8 \\
Sugar content (\%) & 9.46 & 2.975 & 1.913 & 4.887 & 76.5 \\
\hline
\end{tabular}

The values of coefficient variation $(\mathrm{CV})$, genetic $\left(\sigma_{\mathrm{g}}^{2}\right)$, ecological $\left(\sigma^{2}{ }_{\mathrm{e}}\right)$ and phenotypic $\left(\sigma_{p}^{2}\right)$ variances and broad-sense heritability $\left(h^{2}\right)$ (Table 3 ) indicated that the tuber weight per plant was the most variable trait $(\mathrm{CV}=47.12 \%)$ and the sugars content in tubers the least variable trait $(\mathrm{CV}=9.46 \%)$. The variability values of tuber number per plant and average tuber weight were $37.30 \%$ and $36.05 \%$, respectively. Based on these values, it may be concluded that the phenotypic variation of tuber weight per plant, tuber number per plant and average tuber weight was predominantly determined by environmental factors. This was confirmed by the low heritability values for tuber weight per plant, $\mathrm{h}^{2}=28.4 \%$, tuber number per plant, $\mathrm{h}^{2}=35.0 \%$, and average tuber weight, $\mathrm{h}^{2}=27.8 \%$. The low value of correlation coefficient $(\mathrm{CV}=9.46 \%)$, the greater genetic $\left(\sigma_{\mathrm{g}}^{2}=2.975\right)$ than environmental variance $\left(\sigma^{2}{ }_{\mathrm{e}}=1.913\right)$ and the heritability of $76.5 \%$ for sugar content indicated that the main factor determining the sugar content in Jerusalem artichoke tubers was the genotype. 
The values of genetic and phenotypic correlation coefficients (Table 4) show that the genotypic correlations were greater than phenotypic ones. Significant genotypic correlations were recorded between tuber yield per plant and tuber number per plant $\left(r_{g}=0.663\right)$, tuber yield per plant and tuber weight $\left(r_{g}=0.680\right)$ and tuber yield per plant and sugar content $\left(r_{g}=-0.647\right)$. This means that, practically, the tuber yield per plant was equally determined by the number and weight of individual tubers. The increase in tuber yield per plant significantly decreased the sugars content $\left(r_{\mathrm{g}}=-0.647\right)$.

Table 4: Genetic (above) and phenotypic (bellow) correlation coefficients for quantitative traits in the collection of Jerusalem artichoke genotypes.

\begin{tabular}{lcccc}
\hline & $\begin{array}{c}\text { Tuber yield } \\
\text { per plant }(\mathrm{kg})\end{array}$ & $\begin{array}{c}\text { Tuber number } \\
\text { per plant }\end{array}$ & $\begin{array}{c}\text { Tuber } \\
\text { size }(\mathrm{g})\end{array}$ & $\begin{array}{c}\text { Sugar content } \\
(\%)\end{array}$ \\
\hline Tuber yield per plant $(\mathrm{kg})$ & & $0.663^{*}$ & $0.680^{\star *}$ & $-0.647^{*}$ \\
Tuber number per plant & 0.580 & & 0.219 & -0.346 \\
Tuber size $(\mathrm{g})$ & 0.487 & 0.032 & & -0.577 \\
Sugar content $(\%)$ & -0.207 & -0.073 & -0.298 & \\
\hline
\end{tabular}

* Significant at $5 \%$ level

** Significant at $1 \%$ level

Based on 15-year evaluation of the collection of Jerusalem artichoke genotypes, they were classified based on similarities in the dendrogram of phenotypic differences (Figure 1).

The dendrogram contain six clusters with different number of genotypes, mutually linked at different hierarchical levels. The three most distant clusters, those at the ends of the dendrogram, are each comprised of a single cultivar (BT-4, BT-3 and Banja Koviljača). The fourth cluster includes the genotypes UKR 6/82, Ozor and $\mathrm{K}-8$, the fifth the genotype Violet Rennes. The sixth cluster, which includes the remaining thirteen genotypes, is most numerous and most heterogeneous, with genotypes linked at several levels. It can be concluded on the basis of the dendrogram that the analyzed collection of genotypes is significantly divergent regarding the genotypes' yield components.

\section{CONCLUSIONS}

The obtained results indicated that there existed significant phenotypic variabilities among tuber yield per plant, tuber number per plant and tuber weight, which were predominantly due to the environmental conditions. The main factor determining the sugars content in tubers was the genotype. Tuber yield per plant was equally affected by the tuber number per plant and weight of individual tubers. The increase in tuber yield resulted in a significant reduction of sugar content in tubers. The dendrogram of phenotypic differences in yield components of the Jerusalem artichoke varietal collection comprised several clusters, which differed in size and structure and whose members were linked at different hierarchical levels. Regard- 
ing the yield components, best results were achieved with the cultivar BT-4, which formed a separate cluster at the end of the dendrogram and which was linked with the rest of the collection at the highest hierarchical level. The cultivars Violet Rennes, UKR 5/82 and Topianca had highest sugar contents in tubers.

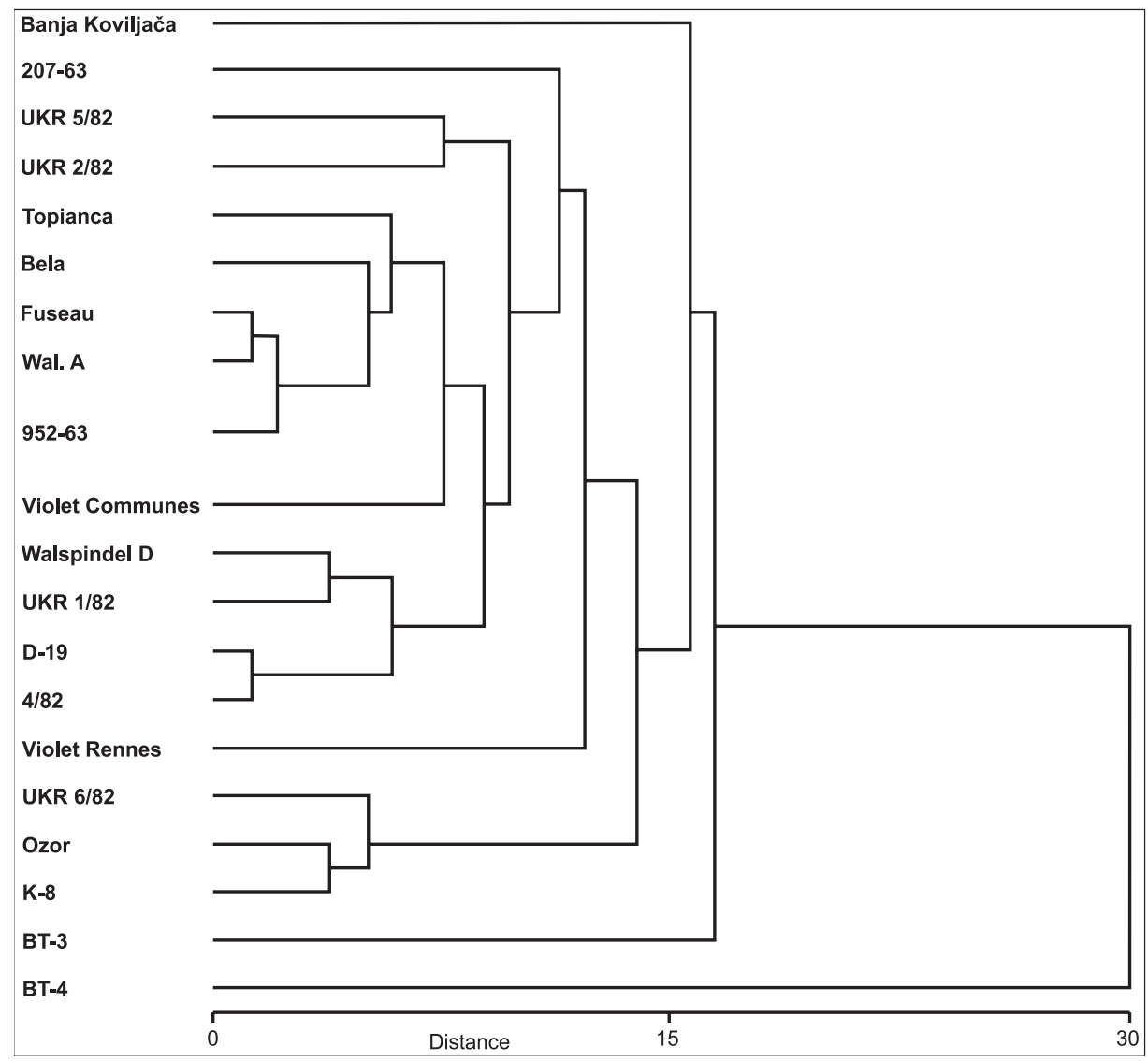

Figure 1: Dendrogram of phenotypic differences in the collection of Jerusalem artichoke genotypes

\section{REFERENCES}

Berenji, J., 1994. Bioalkohol od sirka i čičoke. Revija agronomska saznanja (in Serbian). 4: 19-21.

Berenji, J., Sikora, V., 2001. Variability and stability of tuber yield of Jerusalem artichoke (Helianthus tuberosus L.). Helia 24(35): 25-32.

Fleming, S.E., Groot Wessink, J.W.D., 1979. Preparation of high-fructose syrup from the tubers of the Jerusalem artichoke. CRC Critical Reviews in Food Science and Nutrition. pp. 1-28.

Hill, J., Becker, H.C., Tigerstedt, P.M.A., 1998. Quantitative and ecological aspects of plant breeding. Chapman \& Hall, London.

Kišgeci, J., Berenji, J., Pejin, D., Razmovski, R., Ružić, N., 1988. Bio-alcohol production from sorghum and Jerusalem artichoke. CNRE Bulletin 20: 113-121. 
Klausthofer, H., Abraham, B., Liebhard, P., Bucnik, P., 1987. Results of an investigation of nine Jerusalem artichoke cultivars from autumn and spring harvest 1985/1986. Die Branntweinwirtschaft 127: 2-6.

Korell, M., Brahm, L., Horn, R., Friedt, W., 1996a. Interspecific and intergeneric hybridization in sunflower breeding. I: General breeding aspects. Plant Breeding Abstracts 66: 925-932.

Korell, M., Brahm, L., Horn, R., Friedt, W., 1996b. Interspecific and intergeneric hybridization in sunflower breeding. II: Specific uses of wild germplasms. Plant Breeding Abstracts 66: 1081-1091.

Kosarić, N., Cosentino, G.P., Wieczorek, A., Duvnjak, Z., 1984. The Jerusalem artichoke as an agricultural crop. Biomass 5: 1-36.

Meijer, W.J.M., Mathijssen, E.W.J.M., Borm, G.E.L., 1993. Crop characteristics and inulin production of Jerusalem artichoke and chicory. In: Fuchs, A. [Ed.] Inulin and inulincontaining crops, Studies in Plant Science. Elsevier Sci. Pub., Amsterdam 3: 29-38.

Mullin, W.J., Modler, H.W., Farnworth, E.R., Payne, A., 1994. The macronutrient content of fractions from Jerusalem artichoke tubers. Food Chemistry 51: 263-269.

Schittenhelm, S., 1999. Agronomic performance of root chicory, Jerusalem artichoke, and sugarbeet in stress and nonstress environments. Crop Science 39: 1815-1823.

Seiler, G.J., 1993. Forage and tuber yields and digestibility of selected wild and cultivated genotypes of Jerusalem artichoke. Agronomy Journal 85: 29-33.

Suseelana, K.N., Mitra, R., Pandey, R., Sainis, K.B., Krishnaa, T.G., 2002. Purification and characterization of a lectin from wild sunflower tubers. Archives of Biochemistry and Biophysics 407: 241-247.

Wyse, D.L., Young, F.L., Jones, R.J., 1986. Influence of Jerusalem artichoke density and duration of interference on soybean growth and yield. Weed Science 34: 243-247. 
